FINANCIAL: Jurnal Akuntansi

Published by Program Studi Akuntansi STIE Sultan Agung Volume 5-Nomor 2, Desember 2019, (HIm 57-69)

ISSN-P: 2502-4574, ISSN-E: 2686-2581

Available online at: https://financial.ac.id/index.php/financial

\title{
PERBANDINGAN FINANCIAL DISTRESS PADA PT LIPPO CIKARANG, TbK DAN PT BUKIT DARMO PROPERTY, Tbk DENGAN MENGGUNAKAN METODE SPRINGATE
}

\author{
Pita Merlin Marpaung ${ }^{1)^{*}}$, Elly Susanti ${ }^{2)}$, Christine Dewi Nainggolan ${ }^{3)}$, Musa Fernando Silaen ${ }^{4)}$ \\ ${ }^{1}$ Program Studi Akuntansi, STIE Sultan Agung, Pematangsiantar, Sumatera Utara, Indonesia. \\ ${ }^{2}$ Program Studi Akuntansi, STIE Sultan Agung, Pematangsiantar, Sumatera Utara, Indonesia. \\ ${ }^{3}$ Program Studi Akuntansi, STIE Sultan Agung, Pematangsiantar, Sumatera Utara, Indonesia. \\ ${ }^{4}$ Program Studi Akuntansi, STIE Sultan Agung, Pematangsiantar, Sumatera Utara, Indonesia. \\ *E-mail: ${ }^{1}$ pitamarpaung@gmail.com, ${ }^{2}$ ellysusanti@ stiesultanagung.ac.id, \\ ${ }^{3}$ christine@stiesultanagung.ac.id, ${ }^{4}$ musasilaen@stiesultanagung.ac.id
}

\begin{abstract}
Abstrak
Tujuan dari penelitian ini adalah untuk mengetahui gambaran dan faktor yang menyebabkan perbedaan financial distress pada PT Lippo Cikarang, Tbk dan PT Bukit Darmo Property, Tbk dengan menggunakan metode Springate. Penelitian ini menggunakan data kualitatif dan kuantitatif. Teknik Pengumpulan data dilakukan dengan metode dokumentasi. Sumber data yang digunakan adalah data sekunder yang diperoleh dari situs resmi Bursa Efek Indonesia www.idx.co.id. Teknik analisis data yang digunakan adalah analisis deskriptif kualitatif dan analisis komparatif. Hasil penelitian ini menyimpulkan bahwa PT Lippo Cikarang, Tbk diindikasikan perusahaan tidak bangkrut (sehat) sedangkan PT Bukit Darmo Property, Tbk diindikasikan perusahaan sedang menghadapi ancaman kebangkrutan dan faktor modal kerja bersih yang bernilai negatif disebabkan oleh penurunan persediaan dan penjualan yang bersumber dari penjualan tanah industri, tanah komersial, rumah toko dan adanya peningkatan beban pokok penjualan disebabkan oleh perubahan variasi produk menyebabkan perbedaan financial distress perusahaan. Hasil penelitian ini menyarankan sebaiknya PT Lippo Cikarang, Tbk dan PT Bukit Darmo Property, Tbk meningkatkan pengelolaan aset untuk meningkatkan penjualan atau pendapatan dan meningkatkan laba yang merupakan indikator dalam mencari nilai Springate.
\end{abstract}

Kata kunci: Financal Distress, Metode Springate

\section{COMPARISON OF FINANCIAL DISTRESS IN PT LIPPO CIKARANG AND PT BUKIT DARMO PROPERTY USING SPRINGATE METHOD \\ Abstract}

The purpose of this study is: to determine the description of financial distress in PT Lippo Cikarang, Tbk and PT Bukit Darmo Property, Tbk using the Springate method and what factors cause financial distress differences in PT Lippo Cikarang, Tbk and PT Bukit Darmo Property, Tbk with using the Springate method. This research was conducted using qualitative data and quantitative data. Data collection techniques carried out by the method of documentation. The data source used in this study is secondary data obtained from the official website of the Indonesia Stock Exchange www.idx.co.id. The data analysis technique used is qualitative descriptive analysis and comparative analysis. The results of this study concluded that PT Lippo Cikarang, Tbk indicated the company was not bankrupt (healthy) while PT Bukit Darmo Property, Tbk indicated the company was facing a serious bankruptcy threat (bankrupt). and net working capital factor which is negative due to a decrease in inventory, a decrease in sales that originated from sales of industrial land, commercial land, shop houses and an increase in cost of goods sold due to changes in product variations causing differences in the company's financial distress. The results of this study suggest that PT Lippo Cikarang, Tbk and PT Bukit Darmo Property, Tbk should improve asset management to increase sales or revenue and increase profits, which are indicators in finding the value of Springate

Keywords: Financial Distress, Springate Method

Article History: Received: 21 Nop 2019 Revised: 22 Nop 2019 Accepted: 20 Des 2019 
FINANCIAL: Jurnal Akuntansi, Volume 5 Nomor 2, Desember 2019

\section{PENDAHULUAN}

Financial distress atau kesulitan keuangan akan dialami oleh perusahaan sebelum terjadi kebangkrutan. Financial distress merupakan kondisi krisis ekonomi yang mana perusahaan mengalami kerugian beberapa tahun terakhir karena dianggap tidak mampu membayar kewajiban saat jatuh tempo. Penurunan ekonomi di perusahaan perlu di waspadai oleh pihak manajemen. Oleh sebab itu, pihak manajemen sebaiknya mengambil tindakan dengan melakukan prediksi dini agar dapat memperbaiki kondisi ekonomi perusahaan.

Dalam memprediksi financial distress yang berujung dalam kebangkrutan suatu perusahaan dapat dilakukan dengan berbagai metode dalam menganalisisnya, salah satu metode yang dapat digunakan adalah metode Springate. Selanjutnya Springate juga menentukan batasan (standar) berupa nilai 0,862 untuk memprediksikan perusahaan berpotensi bangkrut atau berpotensi sebagai perusahaan yang sehat (tidak bangkrut). Berikut disajikan Tingkat kesehatan keuangan PT Lippo ikarang, Tbk dan PT Bukit Darmo Property, Tbk tahun 2013-2017 dengan mengunakan Metode Springate.

\section{Tabel 1}

Tingkat Kesehatan Keuangan PT LippoCikarang, Tbk dan PT Bukit Darmo Property, Tbk Tahun 2013-2017 dengan

Menggunakan Metode Springate PT LIPPO CIKARANG, Tbk

\begin{tabular}{|c|c|c|c|c|c|}
\hline Tahun & $\mathbf{A}$ & $\mathbf{B}$ & $\mathbf{C}$ & $\mathbf{D}$ & $\begin{array}{c}\text { S- } \\
\text { Score }\end{array}$ \\
\hline 2013 & 0,3126 & 0,1656 & 0,3407 & 0,3445 & 1,1931 \\
\hline 2014 & 0,4946 & 0,2147 & 0,6159 & 0,4159 & 1,7413 \\
\hline 2015 & 0,5738 & 0,1670 & 0,8155 & 0,3872 & 1,7969 \\
\hline 2016 & 0,6479 & 0,0937 & 0,5963 & 0,2733 & 1,4579 \\
\hline 2017 & 0,6712 & 0,0286 & 0,2184 & 0,1213 & 0,9717 \\
\hline $\begin{array}{c}\text { Rata- } \\
\text { rata }\end{array}$ & $\mathbf{0 , 5 4 0 0}$ & $\mathbf{0 , 1 3 3 9}$ & $\mathbf{0 , 5 1 7 4}$ & $\mathbf{0 , 3 0 8 4}$ & $\mathbf{1 , 4 3 2 2}$ \\
\hline
\end{tabular}

PT BUKIT DARMO PROPERTY, TbK

\begin{tabular}{|c|c|c|c|c|c|}
\hline Tahun & $\mathbf{A}$ & $\mathbf{B}$ & $\mathbf{C}$ & $\mathbf{D}$ & S-Score \\
\hline 2013 & 0,1947 & $-0,0496$ & $-0,7690$ & 0,0135 & $-0,4540$ \\
\hline 2014 & 0,1053 & 0,0386 & 0,0993 & 0,1295 & 0,3445 \\
\hline 2015 & 0,1817 & $-0,0086$ & $-0,3277$ & 0,0760 & $-0,0253$ \\
\hline 2016 & $-0,2396$ & $-0,0120$ & $-0,1020$ & 0,0668 & $-0,3243$ \\
\hline 2017 & $-0,1099$ & $-0,0325$ & $-0,2757$ & 0,0551 & $-0,3731$ \\
\hline $\begin{array}{c}\text { Rata- } \\
\text { rata }\end{array}$ & $\mathbf{0 , 0 2 6 4}$ & $\mathbf{- 0 , 0 1 2 8}$ & $\mathbf{- 0 , 2 7 5 0}$ & $\mathbf{0 , 0 6 8 2}$ & $\mathbf{- 0 , 1 6 6 4}$ \\
\hline
\end{tabular}

Sumber: Data diolah (2019)

Menurut Syahyunan (2015:120), "jika S < 0,862 perusahaan dikategorikan berpotensi bangkrut, jika nilai $0,862<\mathrm{S}<1,062$ mengindikasikan pihak manajemen harus hatihati dalam mengelola asset-aset perusahaan agar tidak terjadi kebangkrutan (daerah rawan bangkrut), dan jika nilai $\mathrm{S}>1.062$ mengindikasikan perusahaan dalam kondisi keuangan yang sehat (tidak bangkrut)".

Berdasarkan Tabel 1 dapat dilihat bahwa PT Lippo Cikarang, Tbk dari tahun 2013-2017 jika diukur dengan menggunakan metode Springate perusahaan dalam kondisi keuangan yang sehat (tidak bangkrut) tetapi tingkat kesehatan keuangan perusahaan mengalami fluktuasi cenderung menurun. Sedangkan PT Bukit Darmo Property, Tbk dari tahun 20132017 jika diukur dengan menggunakan metode Springate perusahaan diindikasikan sedang menghadapi ancaman kebangkrutan yang serius (bangkrut) dan tingkat kesehatan keuangan cenderung menurun. Adapun faktor-faktor penyebab kebangkrutan pada kedua perusahaan tersebut dapat dilihat dari modal kerja, total aset , laba sebelum bunga dan pajak, laba sebelum pajak, utang lancar dan penjualan.

\section{LANDASAN TEORI}

Sujarweni (2015), "akuntansi adalah proses dari transaksi yang dibuktikan dengan faktur, lalu dari transaksi dibuat jurnal, buku besar, neraca lajur, kemudian akan menghasilkan informasi dalam bentuk laporan keuangan yang digunakan pihak-pihak tertentu', 
Martinus (2008), “analisis laporan keuangan adalah suatu proses yang penuh pertimbangan dalam rangka membantu mengevaluasi posisi keuangan dan hasil operasi perusahaan pada masa sekarang dan masa lalu, dengan tujuan utama untuk menentukan estimasi dan prediksi yang paling mungkin mengenai kondisi kinerja perusahaan pada masa yang akan datang".

Almilia dan Kristijadi (2003), "Financial Distress adalah kondisi dimana perusahaan mengalami laba bersih operasi (net operation income) negatif selama beberapa tahun dan selam lebih dari satu tahun tidak melakukan pembayaran dividen, pemberhentian tenaga kerja atau menghilangkan pembayaran dividen." Sedangkan menurut Endri (2009), kebangkrutan adalah suatu keadaanatau situasi dalam hal ini perusahaan gagal atau tidak mampu lagi memenuhi kewajibankewajiban kepada debitur karena perusahaan mengalami kekurangan dan ketidakcukupan dana untuk menjalankan atau melanjutkan usahanya sehingga tujuan ekonomi yang ingin dicapai oleh perusahaan tidak dapat dicapai, yaitu profit, karena laba yang diperoleh perusahaan dapat digunakan untuk mengembalikan pinjaman, membiayai operasi perusahaan dan kewajiban-kewajiban yang harus dipenuhi bisa ditutup dengan laba atau aktiva yang dimiliki."

Menurut penelitian Gamayuni (2011), penyebab kebangkrutan dapat berasal dari faktor internal dan eksternal perusahaan. Faktor internal antara lain kurangnya pengalaman manajemen, kurangnya pengetahuan dalam mempergunakan asset dan liabilities secara efektif. Sedangkan faktor eksternal yaitu inflasi, sistem pajak dan hukum, depresiasi mata uang asing, dan alasanlainnya. Ada pihak-pihak yang akan dirugikan jika suatu perusahaan sampai mengalami kebangkrutan.

Menurut Syahyunan (2015:120), ada 4 metode untuk menilai tingkat kesehatan Copyright (C) 2019, FINANCIAL: Jurnal Akuntansi keuangan suatu perusahaan yaitu sebagai berikut:

\section{Metode Altman Z-Score}

Metode Z-Score merupakan suatu persamaan multivariable yang digunakan oleh Altman dalam rangka memprediksi tingkat kebangkrutan Z-Score asli pertama kali dirumuskan oleh Altman dengan kondisi latar belakang, antara lain:

1) Sample diambil dari perusahaan manufaktur publik.

2) Perusahaan berlokasi di Amerika Serikat.

3) Dirumuskan tahun 1968.

4) Jumlah sample 66 perusahaan, terdiri dari 33 perusahaan bangkrut dan 33 perusahaan tidak bangkrut.

Jumlah rasio dipilih untuk dites adalah 22 buah. Dari jumlah tersebut kemudian hanya dipilih 5 rasio yang paling kuat secara bersama berkolerasi dengan kebangkrutan. Versi pertama dari Z-Score yang asli adalah sebagai berikut:

$$
\begin{aligned}
& \mathrm{Z}=1,2 \mathrm{X}=\frac{\text { Working Capital }}{\text { Total Asset }} \\
&+1,4 \mathrm{X}=\frac{\text { Retained Earning }}{\text { Total Asset }} \\
&+3,3=\frac{\text { EBIT }}{\text { Total Asset }} \\
&+0,6=\frac{\text { Sales }}{\text { Total Asset }}
\end{aligned}
$$

Score:

$>2,99=$ Tidak Bangkrut

$<1,81=$ Bangkrut

$<1,23=$ Bangkrut

Karena keterbatasan dari penggunaan Z-Score yang hanya dapat digunakan untuk perusahaan public dan manufaktur. Kemudian Altman mengembangkan dua varian dari Z-Score yaitu Z'-Score dan Z'-Score. Z'-Score ditunjukan untuk perusahaan non publik (private) dengan cara merumuskan kembali rasio yang digunakan, yaitu menghilangkan Market Value of Equity dan Menggantinya dengan Book Value of Equity. Rumus Z'-Score adalah sebagai berikut : 
FINANCIAL: Jurnal Akuntansi, Volume 5 Nomor 2, Desember 2019

$$
\begin{aligned}
\mathrm{Z}=0,717 \mathrm{X} & =\frac{\text { Working Capital }}{\text { Total Asset }} \\
+0,847 & =\frac{\text { Retained Earning }}{\text { Total Asset }} \\
+3,107 & =\frac{\text { EBIT }}{\text { Total Asset }} \\
+0,420 \mathrm{X} & =\frac{\text { Book Value of Equity }}{\text { Book Value of Debt }} \\
+0,6= & \frac{\text { Sales }}{\text { Total Asset }}
\end{aligned}
$$

Score:

$$
\begin{array}{ll}
>2,90 & \text { Tidak Bangkrut } \\
1,23-2,90 & \text { Daerah Kelabu } \\
<1,23 & \text { Bangkrut }
\end{array}
$$

Kemudian Altman merubah kembali rumus Z'-Score menjadi Z'-Score. Pada model terakhir ini rasio Sales to Total Asset dihilangkan dengan harapan efek industri, dalam pengertian ukuran perusahaan terkait dengan asset atau penjualan dapat dihilangkan. Sampel yang digunakan kemudian diganti dengan perusahaan dari Negara berkembang (Emerging Market), Yaitu Mexico. Z'-Score merupakan rumusan yang paling Fleksibel, karena bisa digunakan untuk perusahaan public maupun Private.

$$
\begin{aligned}
\mathrm{Z}=6,56 \mathrm{X} & =\frac{\text { Working } \text { Capital }}{\text { Total Asset }} \\
+3,26 \mathrm{X} & =\frac{\text { Retained Earning }}{\text { Total Asset }} \\
+6,72 \mathrm{X} & =\frac{\text { EBIT }}{\text { Total Asset }} \\
+1,05 \mathrm{X} & =\frac{\text { Book Value of Equity }}{\text { Book Value of Debt }}
\end{aligned}
$$

Score:

$$
\begin{array}{ll}
>2,60 & \text { Tidak Bangkrut } \\
1,1-2,60 & \text { Daerah Kelabu } \\
<1,1 & \text { Bangkrut }
\end{array}
$$

2. Metode Grover

Metode Grover merupakan metode yang diciptakan dengan melakukan pendesainan dan penilaian ulang terhadap model Altman Z- Score. Pada tahun 1968, dengan menambahkan 13 (tiga belas) rasio keuangan baru, dan kemudian menggunakan Copyright (C) 2019, FINANCIAL: Jurnal Akuntansi
3 (tiga) rasio keuangan yang dianggap paling mempengaruhi kebangkrutan perusahaan. Sample yang digunakan sebanyak 70 perusahaan dengan 35 perusahaan yang bangkrut dan 35 perusahaan yang tidak bangkrut pada tahun 1982 hingga 1996. Grover menghasilkan fungsi sebagai berikut:

Score $=1,650 \mathrm{X}_{1}+3,404 \mathrm{X}_{2}-0,016 \mathrm{ROA}+$ 0,057

Keterangan:

$$
\begin{aligned}
& \mathrm{X}_{1}=\frac{\text { Working Capital }}{\text { Total Asset }} \\
& \mathrm{X}_{2}=\frac{\text { Earning Before Interest and Taxes }}{\text { Total Asset }} \\
& \mathrm{ROA}=\frac{\text { Net Income }}{\text { Total Asset }}
\end{aligned}
$$

Grover mengklasifikasikan nilai kebangkrutan perusahaan sebagai berikut:

1) Jika Score $\leq-0,02$ maka perusahaan dalam keadaan bangkrut

2) Jika Score $\geq-$ 0,01 maka perusahaan dalam keadaan sehat (tidak bangkrut)

3. Model Springate

Analisis kebangkrutan metode Springate ditemukan oleh Springte pada tahun 1978. Sample yang digunakan sebanyak 40 perusahaan dengan mengggunakan metode MDA. Springate menemukan 4 rasio dari 19 rasio keuangan yang paling berkontribusi terhadap prediksi kebangkrutan perusahaan. Keempat rasio keuangan tersebut dikombinasikan dalam suatu formula yang disebut model Springate, secara sistematis dirumuskan sebagai berikut:

$$
S=1,03 \mathrm{~A}+3,07 \mathrm{~B}+0,66 \mathrm{C}+0,4 \mathrm{D}
$$

Dimana:

$$
\begin{aligned}
& \mathrm{A}=\frac{\text { Working Capital }}{\text { Total Asset }} \\
& \mathrm{B}=\frac{\text { Earning Before Interest and Taxes }}{\text { Total Asset }} \\
& \mathrm{C}=\frac{\text { Earning Before Taxes }}{\text { Current Liabilities }} \\
& \mathrm{D}=\frac{\text { Total Sales }}{\text { Total Asset }}
\end{aligned}
$$

Springate membagi kriteria penilaian kebangkrutan perusahaan ke dalam 3 (tiga) kategori: 
1) Jika nilai $\mathrm{S}<0,862$ maka ini adalah data sekunder yang diperoleh dari mengindikasikan perusahaan situs resmi Bursa Efek Indonesia www.idx.co.id. menghadapi ancaman kebangkrutan yang Teknik analisis data yang digunakan adalah serius (bangkrut).

analisis deskriptif kualitatif dan analisis

2) Jika nilai $0,862<\mathrm{S}<1,062$ maka komparatif.

mengindikasikan pihak manajemen harus hati-hati dalam mengola aset-aset perusahaan agar tidak terjadi kebangkrutan (daerah rawan kebangkrutan).

\section{HASIL DAN PEMBAHASAN}

\section{Analisis Tingkat Financial Distress Pada PT Lippo Cikarang, Tbk dan PT Bukit Darmo Property, Tbk}

3) Jika nilai $\mathrm{S}>1,062$ mengidentifikasi perusahaan dalam kondisi keuangan yang sehat (tidak bangrut).

\section{Metode Zmijewski}

Metode analisis kebangkrutan ini ditemukan oleh Zmijewski pada tahun 1963 yang merupakan hasil riset selama 20 tahun. Zmijewski menggunakan 75 perusahaan yang bangkrut dan 3,573 perusahaan yang sehat selama tahun 1970 hingga 1978. Rasio keuangan yang digunakan pada model ini dipilih dari rasio keuangan yang telah digunakan pada penelitian terdahulu. Model Zmijewski yang berhasil dikembangkan, yaitu:

$$
Z=-4,3-4,5 X_{1}+5,7 X_{2}+0,004 X_{3}
$$

Dimana:

$$
\begin{aligned}
& \mathrm{X}_{1}=\text { Return On Asset } \\
& \mathrm{X}_{2}=\text { Debt Ratio } \\
& \mathrm{X}_{3}=\text { Current Ratio }
\end{aligned}
$$

Nilai cut-off yang digunakan dalam model ini adalah 0 , dimana $Z$ jika bernilai positif $(\mathrm{Z}>0)$ berarti perusahaan berpotensi mengalami kebangkrutan. Sedangkan, semakin negative nilai $\mathrm{Z}(\mathrm{Z} \leq 0)$, maka semakin jauh perusahaan dari potensi mengalami kebangkrutan.

\section{METODE}

Penelitian ini dilakukan dengan menggunakan data kualitatif dan data kuantitatif. Teknik Pengumpulan data dilakukan dengan metode dokumentasi. Sumber data yang digunakan dalam penelitian

Tingkat kesehatan keuangan merupakan suatu kondisi yang menggambarkan kemampuan perusahaan dalam mengelola keuangan demi berlangsungnya operasional perusahaan yang efektif dan efisien untuk keberlangsungan hidup perusahaan dalam jangka waktu yang lama. Tingkat kesehatan keuangan dapat diukur dengan metode kebangkrutan salah satunya dalam metode Springate. Metode ini cocok digunakan pada perusahaan diberbagai bidang usaha yang go public dan tidak go public dalam Negara berkembang seperti di Indonesia. Metode Springate secara sistematis dirumuskan sebagai berikut:

$$
\begin{aligned}
& \mathrm{S}=1,03 \mathrm{~A}+3,07 \mathrm{~B}+0,66 \mathrm{C}+0,4 \mathrm{D} \\
& \mathrm{Aorking} \mathrm{Capital} \\
& \mathrm{B}=\frac{\text { Earning Asset }}{\text { Total Asset }} \\
& \mathrm{C}=\frac{\text { Earning Before Taxes }}{\text { Current Liabilities }} \\
& \mathrm{D}=\frac{\text { Total Sales }}{\text { Total Asset }}
\end{aligned}
$$

Adapun rasio A yaitu working capital terhadap total asset digunakan untuk melihat berapa besar modal kerja bersih yang dimiliki perusahaan dari seluruh total asetnya. Rasio B yaitu perbandingan antara earning before interest and tax terhadap total asset digunakan untuk mengukur seberapa efisien perusahaan 
dalam mengelola seluruh asetnya untuk berada pada tahun 2017 sebesar 0,6712 yang menghasilkan EBIT (laba usaha). Rasio C yaitu perbandingan antara earning before tax terhadap current liabilities digunakan untuk mengukur kemampuan EBT dalam menjamini atau menutupi utang lancar yang dimiliki perusahaan. Rasio D yaitu perbandingan antara total sales terhadap total asset digunakan untuk mengukur kemampuan perusahaan dalam mengelola seluruh asetnya untuk menghasilkan pendapatan atau penjualan.

\section{Analisis Tingkat Financial Distress PT Lippo Cikarang, Tbk}

Untuk mencari nilai S-Score, hal yang pertama dilakukan adalah mencari nilai dari rasio A, B, C dan D. Setelah nilai masingmasing rasio diketahui maka dapat diketahui besar nilai S-Score. Langkah pertama yaitu mencari nilai A dimana A dapat diketahui dengan cara membagi modal kerja bersih dengan total aset. Modal kerja bersih dapat diketahui dengan cara mengurangkan aset lancar dengan utang lancar. Adapun nilai rasio A disajikan pada Tabel 3.1 berikut ini:

Tabel 2

Perhitungan Nilai Maksimum, Minimum
dan Rata-rata Rasio A PT Lippo Cikarang,
Tbk

Tahun 2013-2017

\begin{tabular}{|c|c|c|c|}
\hline Tahun & $\begin{array}{c}\text { Modal Kerja } \\
\text { (Rp Penuh) }\end{array}$ & $\begin{array}{c}\text { Total Aset } \\
\text { (Rp Penuh) }\end{array}$ & A \\
\hline 2013 & 1.204 .703 .450 .044 & 3.854 .166 .345 .345 & 0,3126 \\
\hline 2014 & 2.131 .669 .270 .744 & 4.309 .824 .234 .265 & 0,4946 \\
\hline 2015 & 3.142 .681 .718 .170 & 5.476 .757 .336 .509 & 0,5738 \\
\hline 2016 & 3.662 .637 .359 .898 & 5.653 .153 .184 .505 & 0,6479 \\
\hline 2017 & 8.308 .717 .000 .000 & 12.379 .227 .000 .000 & 0,6712 \\
\hline \multicolumn{3}{|c|}{ Nilai Maksimum } & $\mathbf{0 , 6 7 1 2}$ \\
\hline \multicolumn{3}{|c|}{ Nilai Minimum } & $\mathbf{0 , 3 1 2 6}$ \\
\hline \multicolumn{3}{|c|}{ Rata-rata } & $\mathbf{0 , 5 4 0 0}$ \\
\hline
\end{tabular}

Sumber: Data diolah (2019)

Berdasarkan Tabel 2 dapat diketahui bahwa nilai rata-rata rasio A PT Lippo Cikarang, Tbk sebesar 0,5400 yang artinya perusahaan ini memiliki modal kerja bersih sebesar $54 \%$ dari seluruh total aset yang dimiliki perusahaan. Nilai maksimum rasio A artinya perusahaan ini memiliki modal kerja bersih sebesar $67,12 \%$ dari seluruh total aset yang dimiliki perusahaan. Sedangkan nilai minimum rasio A dari perusahaan ini berada di tahun 2013 yaitu sebesar 0,3126, artinya perusahaan ini memiliki modal kerja bersih sebesar 31,26\% dari seluruh total aset yang dimiliki perusahaan.

Perkembangan nilai rasio A PT Lippo Cikarang, Tbk berfluktuasi dan cenderung meningkat. Hal ini disebabkan aset lancar, utang lancar dan modal kerja cenderung meningkat, tetapi peningkatan aset lancar lebih tinggi dibandingkan dengan peningkatan utang lancar.

Selanjutnya mencari nilai rasio B yaitu dengan cara membagikan laba sebelum bunga dan pajak (EBIT) dengan total aset. Adapun nilai rasio B disajikan pada Tabel 2 berikut ini:

\section{Tabel 3}

Perhitungan Nilai Maksimum, Minimum dan Rata-rata Rasio C PT Lippo Cikarang, Tbk Tahun 2013-2017

\begin{tabular}{|c|c|c|c|}
\hline Tahun & $\begin{array}{c}\text { EBT } \\
\text { (Rp Penuh) }\end{array}$ & $\begin{array}{c}\text { Utang Lancar } \\
\text { (Rp Penuh) }\end{array}$ & C \\
\hline 2013 & 665.682 .618 .221 & 1.953 .762 .768 .112 & 0,3407 \\
\hline 2014 & 942.294 .098 .501 & 1.530 .034 .755 .092 & 0,6159 \\
\hline 2015 & 930.517 .532 .765 & 1.140 .995 .759 .536 & 0,8155 \\
\hline 2016 & 549.870 .873 .335 & 922.152 .443 .756 & 0,5963 \\
\hline 2017 & 380.748 .000 .000 & 1.743 .341 .000 .000 & 0,2184 \\
\hline \multicolumn{3}{|c|}{ Nilai Maksimum } & $\mathbf{0 , 8 1 5 5}$ \\
\hline \multicolumn{3}{|c|}{ Nilai Minimum } & $\mathbf{0 , 2 1 8 4}$ \\
\hline Rata-rata \\
\hline
\end{tabular}

Sumber: Data diolah (2019)

Berdasarkan Tabel 3 dapat diketahui bahwa nilai rata-rata rasio $\mathrm{C}$ sebesar 0,5174 yang artinya EBT yang dihasilkan perusahaan mampu menjamin utang lancar sebesar 51,74\%. Nilai maksimum dari rasio $\mathrm{C}$ berada pada tahun 2015 yaitu sebesar 0,8155 artinya EBT yang dihasilkan perusahaan mampu menjamin utang lancar sebesar 81,55\%. Sedangkan nilai minimum rasio $\mathrm{C}$ perusahaan ini berada pada tahun 2017 yaitu sebesar 0,2184 yang artinya EBT yang dihasilkan perusahaan mampu menjamin utang lancar sebesar $21,84 \%$. 
Perkembangan nilai rasio $\mathrm{C}$ perusahaan berfluktuatif namun cenderung menurun. Hal ini disebabkan karena EBT (Earning Before Taxes) dan utang lancar cenderung menurun, tetapi penurunan EBT (Earning Before Taxes) lebih tinggi dibandingkan dengan penurunan utang lancar.

Selanjutnya menghitung nilai rasio $\mathrm{D}$ dengan cara total penjualan dibagi dengan total aset. Adapun nilai rasio D disajikan pada Tabel 4 berikut ini:

\section{Tabel 4}

Perhitungan Nilai Maksimum, Minimum dan Rata-rata Rasio D PT Lippo Cikarang, Tbk Tahun 2013-2017

\begin{tabular}{|c|c|c|c|}
\hline Tahun & $\begin{array}{c}\text { Penjualan } \\
\text { (Rp Penuh) }\end{array}$ & $\begin{array}{c}\text { Total Aset } \\
\text { (Rp Penuh) }\end{array}$ & D \\
\hline 2013 & 1.327 .909 .165 .616 & 3.854 .166 .345 .345 & 0,3445 \\
\hline 2014 & 1.792 .376 .641 .870 & 4.309 .824 .234 .265 & 0,4159 \\
\hline 2015 & 2.120 .553 .079 .169 & 5.476 .757 .336 .509 & 0,3872 \\
\hline 2016 & 1.544 .898 .127 .282 & 5.653 .153 .184 .505 & 0,2733 \\
\hline 2017 & 1.501 .178 .000 .000 & 12.379 .227 .000 .000 & 0,1213 \\
\hline \multicolumn{3}{|c|}{ Nilai Maksimum } & $\mathbf{0 , 4 1 5 9}$ \\
\hline \multicolumn{3}{|c|}{ Nilai Minimum } & $\mathbf{0 , 1 2 1 3}$ \\
\hline \multicolumn{3}{|c|}{ Rata-rata } \\
\hline
\end{tabular}

Sumber: Data diolah (2019)

Berdasarkan Tabel 4 dapat diketahui bahwa nilai rata-rata rasio $\mathrm{D}$ sebesar 0,3084 yang artinya perusahaan mampu menghasilkan penjualan sebesar $30,84 \%$ dari seluruh total aset yang dimiliki perusahaan tersebut. Nilai maksimum rasio D berada pada tahun 2014 yaitu sebesar 0,4159 yang artinya perusahaan mampu menghasilkan penjualan sebesar $41,59 \%$ dari seluruh total aset yang dimiliki perusahaan tersebut. Sedangkan nilai minimum rasio D berada pada tahun 2017 sebesar 0,1213 yang artinya perusahaan mampu menghasilkan penjualan sebesar $12,13 \%$ dari seluruh total aset yang dimiliki perusahaan tersebut.

Perkembangan rasio $\mathrm{D}$ perusahaan berfluktuatif namun cenderung menurun. Hal ini disebabkan karena penjualan dan total aset cenderung menurun, tetapi penurunan penjualan lebih besar dibandingkan dengan penurunan total aset. Penjualan yang menurun disebabkan oleh nilai persediaan yang cenderung meningkat setiap tahunnya, dan total aset meningkat dikarenakan adanya peningkatan nilai piutang setiap tahunnya.

Setelah diketahui nilai rasio A, B, C dan D, maka langkah selanjutnya adalah menghitung nilai S-Score. Adapun nilai S-Score PT Lippo Cikarang, Tbk menggunakan metode Springate disajikan pada Tabel 5 berikut ini:

\section{Tabel 5}

Nilai S-Score PT Lippo Cikarang, Tbk Tahun 2013-2017

\begin{tabular}{|c|c|c|}
\hline Tahun & S-Score & Keterangan \\
\hline 2013 & 1,1931 & Tidak bangkrut \\
\hline 2014 & 1,7413 & Tidak bangkrut \\
\hline 2015 & 1,7969 & Tidak bangkrut \\
\hline 2016 & 1,4579 & Tidak bangkrut \\
\hline 2017 & 0,9717 & Daerah rawan bangkrut \\
\hline Nilai Maksimum & $\mathbf{1 , 7 9 6 9}$ & Tidak bangkrut \\
\hline Nilai Minimum & $\mathbf{0 , 9 7 1 7}$ & Daerah rawan bangkrut \\
\hline Rata-rata & $\mathbf{1 , 4 3 2 2}$ & Tidak bangkrut \\
\hline
\end{tabular}

Sumber: Data diolah (2019)

Berdasarkan Tabel 5 dapat diketahui bahwa rata-rata nilai S-Score PT Lippo Cikarang, Tbk sebesar 1,4322 yang mengindikasikan perusahaan sehat (tidak bangkrut) karena nilai S-Score lebih besar dari 1,062. Nilai maksimum S-Score terjadi pada tahun 2015 yaitu sebesar 1,7969 yang mengindikasikan perusahaan sehat (tidak bangkrut) karena nilai S-Score lebih besar dari 1,062. Sedangkan nilai minimum S-Score terjadi pada tahun 2017 sebesar 0,9717 yang mengindikasikan perusahaan berada di daerah rawan bangkrut karena nilai S-Score berada di antara 0,862 dan 1,062 .

\section{Analisis Tingkat Financial Distress PT Bukit Darmo Property, Tbk}

Langkah pertama yaitu mencari nilai A dimana A dapat diketahui dengan cara membagi modal kerja bersih dengan total aset. Modal kerja bersih dapat diketahui dengan cara mengurangkan aset lancar dengan utang lancar. Adapun nilai rasio A disajikan pada Tabel 6 berikut ini: 
Tabel 6

Perhitungan Nilai Maksimum, Minimum dan Rata-rata Rasio A PT Bukit Darmo Property, Tbk Tahun 2013-2017

\begin{tabular}{|c|c|c|r|}
\hline Tahun & $\begin{array}{c}\text { Modal Kerja } \\
\text { (Rp Penuh) }\end{array}$ & $\begin{array}{c}\text { Total Aset } \\
\text { (Rp Penuh) }\end{array}$ & A \\
\hline 2013 & 164.604 .237 .246 & 845.487 .178 .846 & 0,1947 \\
\hline 2014 & 87.293 .115 .265 & 829.193 .043 .343 & 0,1053 \\
\hline 2015 & 143.763 .070 .968 & 791.161 .825 .436 & 0,1817 \\
\hline 2016 & $(188.115 .464 .942)$ & 785.095 .652 .150 & $-0,2396$ \\
\hline 2017 & $(86.107 .085 .327)$ & 783.494 .758 .697 & $-0,1099$ \\
\hline \multicolumn{3}{|c|}{ Nilai Maksimum } & $\mathbf{0 , 1 9 4 7}$ \\
\hline Nilai Minimum & $\mathbf{- 0 , 2 3 9 6}$ \\
\hline Rata-rata & $\mathbf{0 , 0 2 6 4}$ \\
\hline
\end{tabular}

Sumber: Data diolah (2019)

Berdasarkan Tabel 6 dapat diketahui bahwa nilai rata-rata rasio A PT Bukit Darmo Property, Tbk sebesar 0,0264 yang artinya perusahaan ini memiliki modal kerja bersih sebesar 2,64\% dari seluruh total aset yang dimiliki perusahaan tersebut. Nilai maksimum rasio A berada pada tahun 2013 sebesar 0,1947 yang artinya perusahaan ini memiliki modal kerja bersih sebesar $19,47 \%$ dari seluruh total aset yang dimiliki perusahaan tersebut. Sedangkan nilai minimum rasio A dari perusahaan ini berada di tahun 2016 yaitu sebesar -0,2396, artinya perusahaan ini kekurangan modal kerja bersihnya karena apabila utang lancarnya di tagih maka perusahaan harus memberikan seluruh aset lancarnya sehingga PT Bukit Darmo Property, Tbk kekurangan modal kerja bersihnya sebesar 23,96\%.

Perkembangan nilai rasio A cenderung menurun setiap tahunnya. Hal ini disebabkan karena aset lancar, utang lancar, modal kerja dan total aset cenderung menurun, tetapi penurunan aset lancar lebih tinggi dibandingkan dengan penurunan utang lancar. Aset lancar cenderung menurun terutama pada akun piutang lain-lain pihak ketiga dan persediaan.

Setelah nilai A diketahui selanjutnya mencari nilai $\mathrm{B}$ yaitu dengan cara membagikan laba sebelum bunga dan pajak (EBIT) dengan total aset Adapun nilai rasio B disajikan pada Tabel 7 berikut ini:

\section{Tabel 7}

Perhitungan Nilai Maksimum, Minimum dan Rata-rata Rasio B PT Bukit Darmo Property, Tbk Tahun 2013-2017

\begin{tabular}{|c|c|c|c|}
\hline Tahun & $\begin{array}{c}\text { EBIT } \\
\text { (Rp Penuh) }\end{array}$ & $\begin{array}{c}\text { Total Aset } \\
\text { (Rp Penuh) }\end{array}$ & B \\
\hline 2013 & $(41.951 .184 .560)$ & 845.487 .178 .846 & $-0,0496$ \\
\hline 2014 & 32.048 .185 .183 & 829.193 .043 .343 & 0,0386 \\
\hline 2015 & $(6.842 .706 .629)$ & 791.161 .825 .436 & $-0,0086$ \\
\hline 2016 & $(9.415 .176 .291)$ & 785.095 .652 .150 & $-0,0120$ \\
\hline 2017 & $(25.500 .664 .781)$ & 783.494 .758 .697 & $-0,0325$ \\
\hline \multicolumn{3}{|c|}{ Nilai Maksimum } & $\mathbf{0 , 0 3 8 6}$ \\
\hline \multicolumn{3}{|c|}{ Nilai Minimum } & $\mathbf{- 0 , 0 4 9 6}$ \\
\hline Rata-rata \\
\hline
\end{tabular}

Sumber: Data diolah (2019)

Berdasarkan Tabel 7 dapat diketahui bahwa nilai rata-rata rasio B pada PT Bukit Darmo Property, Tbk sebesar $-0,0128$ yang artinya total aset perusahaan ini tidak mampu menghasilkan EBIT atau setiap Rp 1 total aset mengakibatkan kerugian sebesar 0,0128. Nilai maksimum rasio B berada pada tahun 2014 yaitu sebesar 0,0386 yang artinya perusahaan ini mampu menghasilkan EBIT sebesar 3,86\% dari seluruh total aset yang dimiliki perusahaan tersebut. Sedangkan nilai minimum dari rasio B perusahaan ini berada pada tahun 2013 yaitu sebesar -0,0496, artinya total aset perusahaan ini tidak mampu menghasilkan EBIT atau setiap Rp1 total aset, mengakibatkan kerugian sebesar 0,0496.

Perkembangan nilai rasio $\mathrm{B}$ berfluktuatif namun cenderung menurun setiap tahun. Hal ini disebabkan karena EBIT dan total aset yang cenderung menurun. Nilai EBIT cenderung menurun terutama pada penjualan dan pendapatan lain-lain bersih.

Selanjutnya menghitung nilai rasio $\mathrm{C}$ dengan cara membagi EBT (Earning Before Taxes) dengan utang lancar. Adapun nilai rasio $\mathrm{C}$ disajikan pada Tabel 8 berikut ini:

\section{Tabel 8}

Perhitungan Nilai Maksimum, Minimum dan Rata-rata Rasio C PT Bukit Darmo Property, Tbk Tahun 2013-2017 
FINANCIAL: Jurnal Akuntansi, Volume 5 Nomor 2, Desember 2019

\begin{tabular}{|c|c|c|c|}
\hline Tahun & $\begin{array}{c}\text { EBT } \\
\text { (Rp Penuh) }\end{array}$ & $\begin{array}{c}\text { Utang Lancar } \\
\text { (Rp Penuh) }\end{array}$ & C \\
\hline 2013 & $(57.792 .917 .649)$ & 75.153 .331 .479 & $-0,7690$ \\
\hline 2014 & 14.667 .273 .605 & 147.664 .480 .103 & 0,0993 \\
\hline 2015 & $(22.787 .834 .716)$ & 69.540 .984 .373 & $-0,3277$ \\
\hline 2016 & $(24,226,892,908)$ & 237.437 .805 .967 & $-0,1020$ \\
\hline 2017 & $(38.095 .534 .626)$ & 138.154 .620 .099 & $-0,2757$ \\
\hline \multicolumn{3}{|c|}{ Nilai Maksimum } & $\mathbf{0 , 0 9 9 3}$ \\
\hline \multicolumn{3}{|c|}{ Nilai Minimum } & $\mathbf{- 0 , 7 6 9 0}$ \\
\hline \multicolumn{3}{|c|}{ Rata-rata } \\
\hline
\end{tabular}

Sumber: Data diolah (2019)

Berdasarkan Tabel 8 dapat diketahui bahwa nilai rata-rata rasio $\mathrm{C}$ sebesar $-0,2750$ yang artinya EBT yang dihasilkan perusahaan tidak mampu menjamin utang lancarnya karena perusahaan mengalami kerugian. Nilai maksimum rasio $\mathrm{C}$ berada pada tahun 2014 yaitu sebesar 0,0993 yang artinya EBT yang dihasilkan perusahaan mampu menjamin utang lancar sebesar 9,93\%. Sedangkan Nilai minimum rasio $\mathrm{C}$ berada pada tahun 2013 yaitu sebesar -0,7690 artinya EBT yang dihasilkan perusahaan tidak mampu menjamin utang lancarnya karena perusahaan mengalami kerugian.

Perkembangan nilai rasio $\mathrm{C}$ perusahaan berfluktuatif namun cenderung menurun. Hal ini disebabkan karena EBT (Earning Before Taxes) dan utang lancar cenderung menurun, tetapi penurunan EBT lebih tinggi dibandingkan dengan penurunan utang lancar.

Selanjutnya menghitung nilai $\mathrm{D}$ dengan cara total penjualan dibagi dengan total aset. Adapun nilai rasio D disajikan pada Tabel 9 berikut:

Tabel 9

\section{Perhitungan Nilai Maksimum, Minimum dan Rata-rata Rasio D PT Bukit Darmo Property, Tbk Tahun 2013-2017}

\begin{tabular}{|l|c|c|c|}
\hline Tahun & $\begin{array}{c}\text { Penjualan } \\
\text { (Rp Penuh) }\end{array}$ & $\begin{array}{c}\text { Total Aset } \\
\text { (Rp Penuh) }\end{array}$ & D \\
\hline 2013 & 11.385 .096 .413 & 845.487 .178 .846 & 0,0135 \\
\hline 2014 & 107.391 .372 .309 & 829.193 .043 .343 & 0,1295 \\
\hline 2015 & 60.101 .438 .265 & 791.161 .825 .436 & 0,0760 \\
\hline 2016 & 52.413 .771 .234 & 785.095 .652 .150 & 0,0668 \\
\hline 2017 & 43.188 .508 .734 & 783.494 .758 .697 & 0,0551 \\
\hline \multicolumn{3}{|c|}{ Nilai Maksimum } & $\mathbf{0 , 1 2 9 5}$ \\
\hline \multicolumn{3}{|c|}{ Nilai Minimum } & $\mathbf{0 , 0 1 3 5}$ \\
\hline \multicolumn{3}{|c|}{ Rata-rata } \\
\hline
\end{tabular}

Sumber: Data diolah (2019) 
kebangkrutan yang serius (bangkrut) karena nilai S-Score masih lebih kecil dari 0,862. Sedangkan nilai S-Score minimum berada pada tahun 2013 sebesar $-0,4540$ yang mengindikasikan perusahaan sedang menghadapi ancaman kebangkrutan yang serius (bangkrut) karena nilai S-Score lebih kecil dari 0,862 .

Analisis Perbandingan Financial Distress pada PT Lippo Cikarang, Tbk dan PT Bukit Darmo Property, Tbk dengan Menggunakan Metode Springate

Adapun perbandingan nilai S-Score PT Lippo Cikarang, Tbk dan PT Bukit Darmo Property, Tbk tahun 2013-2017 menggunakan metode Springate disajikan pada Tabel 11 berikut ini:

Tabel 11

Perbandingan Nilai S-Score PT Lippo Cikarang, Tbk dan PT Bukit Darmo Property, Tbk Tahun 2013-2017

\begin{tabular}{|c|c|c|}
\hline \multirow{2}{*}{ Tahun } & \multicolumn{2}{|c|}{ S-Score } \\
\cline { 2 - 3 } & $\begin{array}{c}\text { PT Lippo } \\
\text { Cikarang, } \\
\text { Tbk }\end{array}$ & $\begin{array}{c}\text { PT Bukit } \\
\text { Darmo } \\
\text { Property, Tbk }\end{array}$ \\
\hline 2013 & 1,1931 & $-0,4540$ \\
\hline 2014 & 1,7413 & 0,3445 \\
\hline 2015 & 1,7969 & $-0,0253$ \\
\hline 2016 & 1,4579 & $-0,3243$ \\
\hline 2017 & 0,9717 & $-0,3731$ \\
\hline Rata-rata & $\mathbf{1 , 4 3 2 2}$ & $\mathbf{- 0 , 1 6 6 4}$ \\
\hline
\end{tabular}

Sumber: Data diolah (2019)

Berdasarkan tabel 11 maka dapat digambarkan perkembangan nilai S-Score dalam bentuk grafik sebagai berikut :

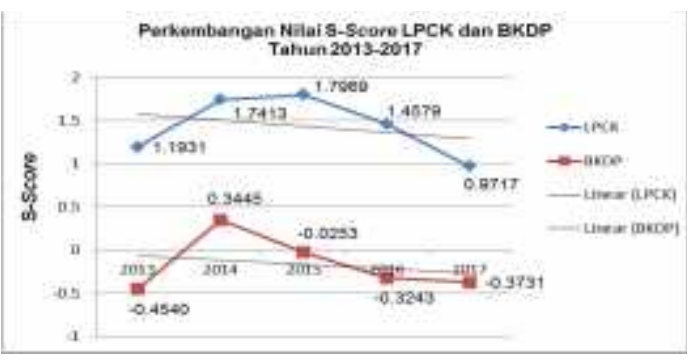

Sumber: Data diolah (2019)

Gambar 1

Perkembangan Nilai S-Score LPCK dan BKDP Tahun 2013-2017

Copyright (C) 2019, FINANCIAL: Jurnal Akuntansi
Berdasarkan Tabel 11 dan gambar 1 menunjukkan bahwa nilai S-Score pada PT Lippo Cikarang, Tbk dari tahun 2013 sampai 2017 berfluktuatif cenderung menurun namun perusahaan diindikasikan berada dalam kondisi keuangan yang sehat (tidak bangkrut) karena nilai rata-rata $\mathrm{S}$-Score lebih besar dari 1,062 yaitu sebesar 1,4322. Hal ini disebabkan rasio B, rasio $\mathrm{C}$ dan rasio $\mathrm{D}$ cenderung menurun namun penurunan paling didominasi rasio $\mathrm{C}$. Adapun yang menyebabkan rasio $\mathrm{C}$ menurun adalah karena adanya penurunan EBT yang berasal dari penurunan penjualan, penurunan ini disebabkan oleh penurunan penjualan tanah industri, tanah komersial dan rumah toko.

Beban pokok penjualan meningkat yang disebabkan oleh perubahan variasi produk sejalan dengan perubahan pendapatan. Selain itu utang lancar juga menurun namun penurunan utang lancar tidak lebih besar dibandingkan penurunan EBT. Sementara nilai rasio A cenderung meningkat yang disebabkan tahun 2013-2017 modal kerja bersih perusahaan ini mengalami peningkatan setiap tahunnya sehingga perusahaan masih diindikasikan sebagai perusahaan sehat karena memiliki modal kerja bersih yang cenderung meningkat.

Sedangkan, PT Bukit Darmo Property, Tbk dari tahun 2013 sampai 2017 berfluktuatif cenderung menurun dan perusahaan diindikasikan berada dalam ancaman kebangkrutan yang serius (bangkrut) karena nilai S-Score kurang dari atau lebih kecil dari 0,862 yaitu sebesar $-0,1664$. Hal ini disebabkan rasio $\mathrm{A}$, rasio $\mathrm{B}$, rasio $\mathrm{C}$, dan rasio $\mathrm{D}$ cenderung menurun. Tetapi penurunan paling didominasi rasio $\mathrm{C}$. Adapun yang menyebabkan penurunan rasio $\mathrm{C}$ adalah karena adanya penurunan EBT (EBT bernilai negatif) setiap tahun yang disebabkan oleh penurunan penjualan dan pendapatan lain-lain bersih namun beban usaha mengalami peningkatan yang disebabkan oleh beban penjualan, beban umum \& administrasi, beban bunga pinjaman bank, beban pajak final 
dan beban lain-lain dan hal ini merupakan penyebab perusahaan berada dalam zona bangkrut.

\section{Evaluasi}

Evaluasi Tingkat Financial Distress Pada PT Lippo Cikarang, Tbk Tahun 2013-2017 dengan Menggunakan Metode Springate

Berdasarkan Tabel 1 dapat diketahui bahwa rasio A PT Lippo Cikarang, Tbk berfluktuatif cenderung meningkat setiap tahunnya yang disebabkan meningkatnya modal kerja bersih dan total aset dikarenakan adanya peningkatan aset lancar dan cenderung menurunnya nilai utang lancar setiap tahunnya.

Berdasarkan Tabel 2 dapat diketahui bahwa rasio B PT Lippo Cikarang, Tbk berfluktuatif cenderung menurun setiap tahunnya, hal ini disebabkan karena penurunan nilai EBIT namun total aset mengalami peningkatan dengan kata lain perusahaan ini belum efisien dalam mengelola seluruh asetnya sehingga EBIT mengalami penurunan setiap tahunnya.

Berdasarkan Tabel 3 dapat diketahui bahwa rasio C PT Lippo Cikarang, Tbk berfluktuatif cenderung menurun, hal ini disebabkan karena EBT menurun. Adapun faktor yang menyebabkan EBT menurun adalah adanya penurunan penjualan yang bersumber dari penurunan penjualan tanah industri, tanah komersial dan rumah toko. Beban pokok penjualan meningkat yang disebabkan oleh perubahan variasi produk sejalan dengan perubahan di pendapatan. Selain itu utang lancar juga menurun namun penurunan utang lancar tidak lebih besar dibandingkan penurunan EBT.

Berdasarkan Tabel 4 dapat diketahui bahwa rasio $\mathrm{D}$ berfluktuatif cenderung menurun. Adapun faktor yang menyebabkan penurunan ini dikarenakan penurunan penjualan dan total aset meningkat dikarenakan kenaikan aset lancar karena beban dan pajak Copyright (C) 2019, FINANCIAL: Jurnal Akuntansi dibayar dimuka, piutang usaha, dan aset tidak lancar.

Evaluasi Tingkat Financial Distress Pada PT Bukit Darmo Property, Tbk Tahun 2013-2017 dengan Menggunakan Metode Springate

Berdasarkan Tabel 6 dapat diketahui bahwa rasio A PT Bukit Darmo Property, Tbk berfluktuatif cenderung menurun setiap tahunnya yang disebabkan menurunnya modal kerja bersih bahkan bernilai negatif dan total aset menurun dikarenakan adanya penurunan aset lancar dan cenderung menurunnya nilai utang lancar setiap tahunnya. Namun penurunan utang lancar tidak lebih besar dibandingkan penurunan aset lancar.

Berdasarkan Tabel 7 dapat diketahui bahwa rasio B PT Bukit Darmo Property, Tbk berfluktuatif cenderung menurun. Hal ini disebabkan karena adanya penurunan penjualan sehingga perusahaan tidak mampu menghasilkan EBIT dan perusahaan cenderung mengalami kerugian setiap tahunnya serta adanya peningkatan total aset yang dikarenakan persediaan ang meningkat.

Berdasarkan Tabel 8 dapat diketahui bahwa rasio C PT Bukit Darmo Property, Tbk berfluktuasi cenderung menurun, hal ini disebabkan karena EBT menurun dan bernilai negatif. Adapun faktor yang menyebabkan EBT menurun adalah menurunnya nilai penjualan. Beban usaha yang ditanggung perusahaan mengalami peningkatan terutama disebabkan oleh beban penjualan, beban umum \& administrasi, beban bunga pinjaman bank, beban pajak final dan beban lain-lain.

Berdasarkan Tabel 3.9 dapat diketahui bahwa rasio D PT Bukit Darmo Property, Tbk berfluktuatif cenderung menurun. Adapun faktor yang menyebabkan penurunan ini dikarenakan penurunan penjualan dan penurunan total aset, tetapi penurunan total aset tidak lebih besar dibandingkan dengan penurunan penjualan. 


\section{KESIMPULAN DAN SARAN}

\section{Kesimpulan}

Simpulan dari penelitian ini adalah atarata nilai S-Score pada PT Lippo Cikarang, Tbk selama 5 tahun mengindikasikan perusahaan berada dalam kondisi keuangan yang sehat (tidak bangkrut) tetapi tingkat kesehatan keuangan cenderung menurun disebabkan oleh rata-rata pertumbuhan EBT periode 2013-2017 cenderung menurun, sedangkan rata-rata pertumbuhan modal kerja bersih selama 5 tahun meningkat, rata-rata pertumbuhan aset lancar meningkat, rata-rata pertumbuhan utang lancar menurun, rata-rata pertumbuhan EBIT menurun dan rata-rata pertumbuhan penjualan selama 5 tahun cenderung menurun. Selanjutnya Rata-rata nilai S-Score pada PT Bukit Darmo Property, Tbk selama 5 tahun mengindikasikan bahwa perusahaan berada dalam kondisi keuangan yang tidak sehat (bangkrut) dan tingkat kesehatan keuangan perusahaan pada tahun 2013-2017 cenderung menurun. Hal ini disebabkan oleh modal kerja yang bernilai negatif, rata-rata pertumbuhan aset lancar dan utang lancar cenderung menurun, rata-rata pertumbuhan EBIT dan EBT cenderung menurun dan rata-rata pertumbuhan penjualan selama 5 tahun cenderung menurun. Faktor yang menyebabkan perbedaan tingkat financial distress PT Lippo Cikarang, Tbk dan PT Bukit Darmo Property, Tbk yaitu modal kerja bersih yang bernilai negatif disebabkan oleh penurunan persediaan, adanya penurunan penjualan yang bersumber dari penjualan tanah industri, tanah komersial, rumah toko dan adanya peningkatan beban pokok penjualan disebabkan oleh perubahan variasi produk menyebabkan perbedaan financial distress perusahaan.

\section{Saran}

Saran untuk penelitian ini adalah sebagai berikut untuk menghindari financial distress pada PT Lippo Cikarang, Tbk sebaiknya perusahaan melakukan penghematan biaya secara keseluruhan sehingga dapat meningkatkan laba serta segera melunasi utang yang telah jatuh tempo guna untuk meminimalisir besarnya beban keuangan yang akan dibayarkan nantinya. Untuk meningkatkan nilai S-Score pada PT Bukit Darmo Property, Tbk, nilai aset lancar harus lebih besar dibandingkan utang lancar sehingga modal kerja bersih tidak bernilai negatif. Sebaiknya, perusahaan meningkatkan pengelolaan aset lancarnya dan mengurangi utang lancarnya seperti utang usaha pihak ketiga dan utang lain-lainnya sehingga mengurangi beban tetap yang harus dibayar oleh perusahaan.

\section{DAFTAR PUSTAKA}

Almilia, Luciana Spica dan Kritijad. (2003). Analisa Rasio Keuangan untuk Memprediksi Kondisi Financial Distress Perusahaan Food and Beverages yang terdaftar di BEJ. Jurnal Akuntansi dan Auditing Indonesia, 7 (2), 183-210. Retrieved from http://journal.uii.ac.id/JAAI/article/view/84 $\underline{6 / 765}$

Endri. (2009). Prediksi Kebangkrutan Bank Untuk Menghadapi dan Mengelola Perubahan Lingkungan Bisnis: Analisis Model Altman Z-Score. Perbanas Quarterly Review, 2 (1), 34-50. Retrieved from

http://repository.perbanas.id/xmlui/handle/ $\underline{123456789 / 937}$

Gamayuni, Rindu Rika. (2011). Analisis Ketepatan Model Altman sebagai Alat untuk Memprediksi Kebangkrutan (Studi Empiris pada Perusahaan Manufaktur di BEI). Jurnal Akuntansi Dan Keuangan, 16 (2), 158-176. Retrieved from http://feb.unila.ac.id/wpcontent/uploads/2015/08/JAK-Juli-011.pdf Ristardi, Martinus (2008). Analisis Laporan Keuangan Untuk Menilai Kinerja Perusahaan. Skripsi, dipublikasikan. Universitas Sanata Dharma Yogyakarta. 
FINANCIAL: Jurnal Akuntansi, Volume 5 Nomor 2, Desember 2019

Rudianto. 2013. Akuntansi Manajemen. Jakarta: Erlangga.

Subramanyam, K. R dan John J. Wild. 2010.

Analisis Laporan Keuangan: Financial

Statement Analysis. Edisi X. Buku Satu.

Jakarta: Salemba Empat.

Sujarweni, V. Wiratna. 2015. Sistem

Akuntansi. Cetakan Pertama. Yogyakarta:

Penerbit Pustaka Baru Press.

\section{PROFIL SINGKAT}

Pita Merlin Marpaung, Pendidikan terakhir Sarjana Akuntansi dari STIE Sultan Agung Tahun 2019. Elly Susanti, Pendidikan terakhir Pascasarjana Program Studi Akuntansi dari Universitas Sumatera Utara Tahun 2013 dan sekarang bekerja sebagai Dosen Tetap bidang Akuntansi STIE Sultan Agung. Christine Dewi Nainggolan, Pendidikan terakhir Pascasarjana Program Studi Akuntansi dari Universitas Sumatera Utara Tahun 2017 dan sekarang bekerja sebagai Dosen Tetap bidang Akuntansi STIE Sultan Agung. Musa Fernando Silaen, Pendidikan terakhir Pascasarjana Program Studi Akuntansi Universitas Muhammadiyah Sumatera Utara Tahun 2018 dan sekarang bekerja sebagai Dosen Tetap bidang Akuntansi STIE Sultan Agung. 